Article

\title{
Biofilm Formation by Shiga Toxin-Producing Escherichia coli on Stainless Steel Coupons as Affected by Temperature and Incubation Time
}

\author{
Zhi Ma ${ }^{1,2,3}$, Emmanuel W. Bumunang ${ }^{2,3}{ }^{\mathbb{D}}$, Kim Stanford ${ }^{3 \oplus}$, Xiaomei Bie ${ }^{1, *}$, Yan D. Niu ${ }^{4} \mathbb{D}$ \\ and Tim A. McAllister $2, *$ (D) \\ 1 College of Food Science and Technology, Nanjing Agriculture University, Nanjing 210095, China; \\ mazhi19900504@sina.com \\ 2 Agriculture and Agri-Food Canada, Lethbridge, AB T1J 4B1, Canada; emmanuel.bumunang@canada.ca \\ 3 Alberta Agriculture and Forestry, Lethbridge, AB T1J 4V6, Canada; kim.stanford@gov.ab.ca \\ 4 Faculty of Veterinary Medicine, University of Calgary, Calgary, AB T2N 4Z6, Canada; \\ dongyan.niu@ucalgary.ca \\ * Correspondence: bxm43@njau.edu.cn (X.B.); tim.mcallister@canada.ca (T.A.M.)
}

Received: 2 March 2019; Accepted: 27 March 2019; Published: 31 March 2019

check for updates

\begin{abstract}
Forming biofilm is a strategy utilized by Shiga toxin-producing Escherichia coli (STEC) to survive and persist in food processing environments. We investigated the biofilm-forming potential of STEC strains from 10 clinically important serogroups on stainless steel at $22{ }^{\circ} \mathrm{C}$ or $13{ }^{\circ} \mathrm{C}$ after 24,48 , and $72 \mathrm{~h}$ of incubation. Results from crystal violet staining, plate counts, and scanning electron microscopy (SEM) identified a single isolate from each of the O113, O145, O91, O157, and O121 serogroups that was capable of forming strong or moderate biofilms on stainless steel at $22{ }^{\circ} \mathrm{C}$. However, the biofilm-forming strength of these five strains was reduced when incubation time progressed. Moreover, we found that these strains formed a dense pellicle at the air-liquid interface on stainless steel, which suggests that oxygen was conducive to biofilm formation. At $13{ }^{\circ} \mathrm{C}$, biofilm formation by these strains decreased $(P<0.05)$, but gradually increased over time. Overall, STEC biofilm formation was most prominent at $22{ }^{\circ} \mathrm{C}$ up to $24 \mathrm{~h}$. The findings in this study identify the environmental conditions that may promote STEC biofilm formation in food processing facilities and suggest that the ability of specific strains to form biofilms contributes to their persistence within these environments.
\end{abstract}

Keywords: Shiga toxin-producing Escherichia coli (STEC); biofilm formation; temperature; stainless steel

\section{Introduction}

Currently, biofilm formation has gained considerable attention in food processing environments. The attachment of microorganisms and subsequent development of biofilms in these environments may be a leading cause of the adulteration of food, which results from the biofouling of pipelines and processing equipment [1]. In addition, biofilms of spoilage and pathogenic microflora that form on contact surfaces are often responsible for the contamination of food during post-processing production $[2,3]$. It has been shown that, even with diligent cleaning and sanitation, microorganisms within biofilms can remain viable on equipment surfaces [4].

Bacteria can readily bind to stainless steel and polymer surfaces in food production systems and form biofilms where cells are embedded within a matrix made up of proteins, carbohydrates, and extracellular DNA $[5,6]$. Portions of mature biofilm often detach and are able to colonize 
downstream environments [7]. Biofilm formation in food processing environments increases the resistance of cells to a number of stressors including starvation, heat, cold, and sanitizers [8,9].

Shiga toxin-producing Escherichia coli (STEC) are foodborne pathogens responsible for human enteric infections [10]. They are associated with important public health concerns worldwide. Symptoms associated with STEC infections range from abdominal cramps and bloody diarrhea to post-infection complications arising from hemolytic-uremic syndrome [11]. According to the Public Health Agency of Canada [12], more than 652 cases of STEC infections occur in Canada each year. The rate of STEC O157:H7 has remained relatively constant at 1.2 cases per 100,000 people per year since 2010. For STEC non-O157, the incidence rate increased slightly between 2010 and 2016 from 0.25 to 0.6 cases per 100,000 people per year. STEC O157:H7 is the most predominant serotype causing outbreaks, but other STEC serogroups, such as O26, O45, O91, O103, O111, O113, O121, O128, and $\mathrm{O} 145$, have also been linked to severe illness $[13,14]$. Although the first reported infections by STEC were associated with contaminated meat, foods such as cheese, vegetables, and drinking water have also been implicated in STEC outbreaks [15-17]. STEC isolates of different origins (i.e., animal, food, and human) can form strong biofilms on various food-contact surfaces [17]. The extracellular matrix of STEC biofilms mainly consists of proteins, poly- $\mathrm{N}$-acetylglucosamine, cellulose, and colanic acid [5]. Although biofilm formation by STEC isolates is influenced by temperature and time [9], researchers have found that the number of STEC O157:H7 reached up to $5 \log \mathrm{CFU} / \mathrm{mL}$ in beef juice at $4{ }^{\circ} \mathrm{C}$ over $72 \mathrm{~h} \mathrm{[6]}$. Thus, STEC biofilms are a potential threat to food hygiene and may become a source of infectious disease in both farm and food-processing environments.

Numerous studies have evaluated the impact of STEC O157 biofilms on food safety, as well as understanding the mechanisms and genetic basis for biofilm formation by this pathogen $[18,19]$. In contrast, there are relatively few reports on the ability of non-O157 STEC to form biofilms on food-contact surfaces. Adator et al. demonstrated that 12 non-O157 strains remained viable within dry-surface biofilms on stainless steel for at least 30 days and were able to contaminate fresh lettuce within 2 min of exposure [17]. Furthermore, Rong et al. showed that O26:H11 and O111:H8 exhibited a superior ability to form biofilms at the air-liquid interface on glass surfaces and be insensitive to sanitizers [20]. These studies demonstrated that non-O157 can adhere to food contact surfaces and subsequently result in contamination of vegetables and meat.

Thirty-six non-O157 STEC strains from nine serogroups (O113, O145, O91, O26, O121, O128, O103, $\mathrm{O} 45$, and O111) were investigated for biofilm formation on polystyrene in our previous study [21]. Of these strains, EC20020170 O113:H21, EC19990166 O145:H25, EC20010076 O91:H21, EC19970119 O26:H11, EC19990161 O121:H19, EC19960949 O128:NM, EC19970327 O103:H2, EC19940040 O45:H2, and EC20030053 O111:NM from each serogroup formed strong biofilms on polystyrene at $22{ }^{\circ} \mathrm{C}$ and $37^{\circ} \mathrm{C}$ [21]. This finding coupled with the previous studies motivated us to further explore their biofilm-forming abilities on stainless steel, since it is the most common contact surface used in food-processing plants. In addition, we included a representative O157 strain of phage type 14a, which is the predominant phage type isolated from humans in Canada. Therefore, the objective of this study was to investigate the biofilm forming potential of STEC over time on stainless steel surfaces at different temperatures.

\section{Materials and Methods}

\subsection{Bacterial Strains and Cultivation}

EC20020170 O113:H21, EC19990166 O145:H25, EC20010076 O91:H21, EC19970119 O26:H11, EC19990161 O121:H19, EC19960949 O128:NM, EC19970327 O103:H2, EC19940040 O45:H2, EC20030053 O111:NM, and EC2011007 O157:H7 were kindly provided by Dr. Roger Johnson of the Public Health Agency of Canada (Guelph, ON, USA). All strains were streaked onto Lysogeny broth (LB) agar (Sigma-Aldrich, Oakville, ON, USA) and incubated at $37^{\circ} \mathrm{C}$ for $18 \mathrm{~h}$. An isolated colony was then 
inoculated into $10 \mathrm{~mL}$ of Minimal Salt (M9) broth (Sigma-Aldrich) supplemented with $0.4 \%$ glucose, $0.02 \% \mathrm{MgSO}_{4}$, and $0.001 \% \mathrm{CaCl}_{2}(w / v)$ and grown at $37^{\circ} \mathrm{C}$, on a rocker platform at $180 \mathrm{rpm}$ for $18 \mathrm{~h}$.

\subsection{Biofilm Formation}

Type-304 stainless steel coupons (No. $2 \mathrm{~b}$ finish, $2.54 \mathrm{~cm} \times 7.62 \mathrm{~cm} \times 0.081 \mathrm{~cm}$, Biosurface, Bozeman, MT, USA) were used to assess biofilm formation. Prior to use, coupons were soaked in 10\% bleach $(0.5 \%$ hypochlorite) for $24 \mathrm{~h}$. This was followed by rinsing three times with sterile distilled water to remove residual hypochlorite and then dried in the biosafety cabinet. Coupons were then treated with $70 \%$ ethanol and air-dried for $5 \mathrm{~min}$ at room temperature. Lastly, the coupons were autoclaved at $121{ }^{\circ} \mathrm{C}$ for $15 \mathrm{~min}$.

To assess biofilm formation, a conventional static assay was used with minor modifications [22]. Briefly, overnight STEC cultures were diluted in M9 medium to achieve a final concentration of $7 \log \mathrm{CFU} / \mathrm{mL}$. Subsequently, $20 \mathrm{~mL}$ of the diluted cultures were introduced into $50 \mathrm{~mL}$ falcon tubes containing a sterile stainless steel coupon. The tubes were loosely capped and incubated at $13^{\circ} \mathrm{C}$ or $22{ }^{\circ} \mathrm{C}$ for 24,48 , or $72 \mathrm{~h}$ at which point biofilm formation was assessed. Two replicate coupons for each strain were evaluated, and coupons in un-inoculated medium were used as negative controls. Data are presented as the average of three independent trials.

\subsection{Crystal Violet Staining}

Following incubation, the coupons were carefully removed from the growth medium using sterile forceps, gently tapped against the side of the falcon tube to remove excess liquid, and rinsed three times with $25 \mathrm{~mL}$ of sterile filtered water to remove loosely-adherent bacteria. Subsequently, the coupons with attached bacterial cells were fixed with $25-\mathrm{mL}$ absolute methanol (analytical grade, $>99 \%$, Sigma-Aldrich) for $15 \mathrm{~min}$. Coupons were air-dried for $2 \mathrm{~min}$, and stained with $0.5 \%(w / v)$ crystal violet solution (Sigma-Aldrich) for $15 \mathrm{~min}$, which was followed by three washes with distilled water and air-drying. The dye bound to the biofilm was then dissolved with $25 \mathrm{~mL}$ of $33 \%$ glacial acetic acid (Sigma-Aldrich) and measured at a wavelength of $590 \mathrm{~nm}$ using a spectrophotometer as described previously [21].

\subsection{Enumeration of the Planktonic and Attached Cells}

To enumerate the planktonic cells after each period, $1 \mathrm{~mL}$ of the cell suspension was pipetted from the falcon tubes, serially diluted with $10 \mathrm{mM}$ phosphate buffered saline (PBS, pH 7.4), plated on LB agar, and incubated at $37^{\circ} \mathrm{C}$ for $18 \mathrm{~h}$. To recover the attached bacterial cells, the coupons were rinsed three times with sterile water, immersed into $25 \mathrm{~mL}$ of sterile PBS, and sonicated at $20 \mathrm{kHz}$ for $10 \mathrm{~min}$. After sonication, the tubes containing coupons were vigorously vortexed for $1 \mathrm{~min}$, and $1 \mathrm{~mL}$ of the bacterial suspension was serially diluted, plated on LB agar, and incubated at $37^{\circ} \mathrm{C}$ for $18 \mathrm{~h}$. Bacteria were enumerated and the results were expressed as the average of the data from three independent assays.

\subsection{SEM Analysis}

Based on the above assays, three strong biofilm formers (strains O113, O145 and O91) were further observed by scanning electron microscopy (SEM), as described previously [23]. Coupons with biofilms were rinsed three times as described above, air-dried, and then fixed in $2.5 \%$ glutaraldehyde $(v / v)$ for $24 \mathrm{~h}$. Subsequently, the samples were dehydrated in a series of ethanol dilutions $(v / v)($ i.e., $10 \%$, $30 \%, 50 \%, 70 \%, 90 \%$, and $100 \%$ ) and isobutyl alcohol dilutions $(v / v)$ (i.e., $10 \%, 30 \%, 50 \%, 70 \%, 90 \%$, and $100 \%$ ). The samples were then treated with $100 \%(v / v)$ hexamethyldisilazane for $10 \mathrm{~min}$ and coated with gold using a sputter coater and visualized using a SEM (HITACHI S-4800, Japan). 


\subsection{Statistical Analysis}

Results from biofilm formation were compiled from the three independent experiments. Data were reported as the averages of replicates \pm the standard deviation. The student's $t$-test and one-way ANOVA with the SPSS software (19.0, IBM, Armonk, NY, USA) were used to calculate $P$ values among treatment groups. Significant differences were presented at a 95\% confidence level $(P \leq 0.05)$.

\section{Results}

\subsection{Growth of the Planktonic Cells in M9 Medium}

As shown in Figure S1, all strains grew well and exhibited similar growth patterns at $22{ }^{\circ} \mathrm{C}$, which reached the stationary phase within $24 \mathrm{~h}$ at about $9 \log \mathrm{CFU} / \mathrm{mL}$, but, at $13^{\circ} \mathrm{C}$, it required $72 \mathrm{~h}$ for cultures to reach an average of $8.5 \log \mathrm{CFU} / \mathrm{mL}$.

\subsection{Biofilm Formation by STEC on a Stainless Steel Surface}

The STEC isolates differed in their ability to form biofilms on stainless steel (Figure 1A). Based on the $\mathrm{OD}_{590 \mathrm{~nm}}$ produced by biofilms, strains were classified as no biofilm, weak, moderate, or strong biofilm producers, as previously described [24]. The cutoff optical density value (ODc) of 0.043 was three standard deviations above the mean $\mathrm{OD}$ of negative controls. Isolates were classified as no $\left(\mathrm{A}_{590}<0.043\right)$, weak $\left(0.086>\mathrm{A}_{590}>0.043\right)$, moderate $\left(0.172>\mathrm{A}_{590}>0.086\right)$, or strong biofilm formers $\left(\mathrm{A}_{590}>0.172\right.$; Figure $\left.1 \mathrm{~B}\right)$. At $22^{\circ} \mathrm{C}, \mathrm{O} 113$ exhibited the highest biofilm-forming capacity $(P<0.05)$, followed by O145, O91, O157, and O121, respectively. The isolates from serogroups O26, O103, O128, $\mathrm{O} 111$, and $\mathrm{O} 45$ formed only weak biofilms. We also found that the attached biomass of strains O113, $\mathrm{O} 145, \mathrm{O} 91, \mathrm{O} 157$, and $\mathrm{O} 121$ decreased $(P<0.05)$ with incubation time at $22^{\circ} \mathrm{C}$ (Figure 1B). Compared to $22^{\circ} \mathrm{C}$, the biofilm formation of isolates from serogroups $\mathrm{O} 113, \mathrm{O} 145, \mathrm{O} 91, \mathrm{O} 157$, and $\mathrm{O} 121$ decreased $(P<0.05)$ at $13{ }^{\circ} \mathrm{C}$. Only the isolate from serogroup $\mathrm{O} 113$ formed a moderate biofilm at $13^{\circ} \mathrm{C}$ after $72 \mathrm{~h}$ of incubation.

\subsection{Enumeration of the Biofilm Cells}

Populations of biofilm cells of strains O113, O145, O91, O157, and O121 all reached approximately $7.0 \log \mathrm{CFU} / \mathrm{cm}^{2}$ at $22{ }^{\circ} \mathrm{C}$ after $24 \mathrm{~h}$, but consistently decreased $(P<0.05)$ to less than $5.9 \log \mathrm{CFU} / \mathrm{cm}^{2}$ by $72 \mathrm{~h}$ (Figure 2). The number of biofilm cells for these five isolates ranged from 2.0 to $3.3 \log \mathrm{CFU} / \mathrm{cm}^{2}$ at $13{ }^{\circ} \mathrm{C}$ at $24 \mathrm{~h}$, achieving 5.5 to $6.4 \log \mathrm{CFU} / \mathrm{cm}^{2}$ over $72 \mathrm{~h}$. In contrast, there was no difference in the number of biofilm cells of $\mathrm{O} 111, \mathrm{O} 128, \mathrm{O} 103, \mathrm{O} 26$, and $\mathrm{O} 45$ at $22{ }^{\circ} \mathrm{C}$, with the concentration remaining between 4.1 to $4.9 \log \mathrm{CFU} / \mathrm{cm}^{2}$. However, the populations of these five isolates did increase from 1.1 to $3.1 \log \mathrm{CFU} / \mathrm{cm}^{2}$ at $24 \mathrm{~h}$ and from 4.1 to $4.8 \log \mathrm{CFU} / \mathrm{cm}^{2}$ after $72 \mathrm{~h}$ at $13^{\circ} \mathrm{C}$. 


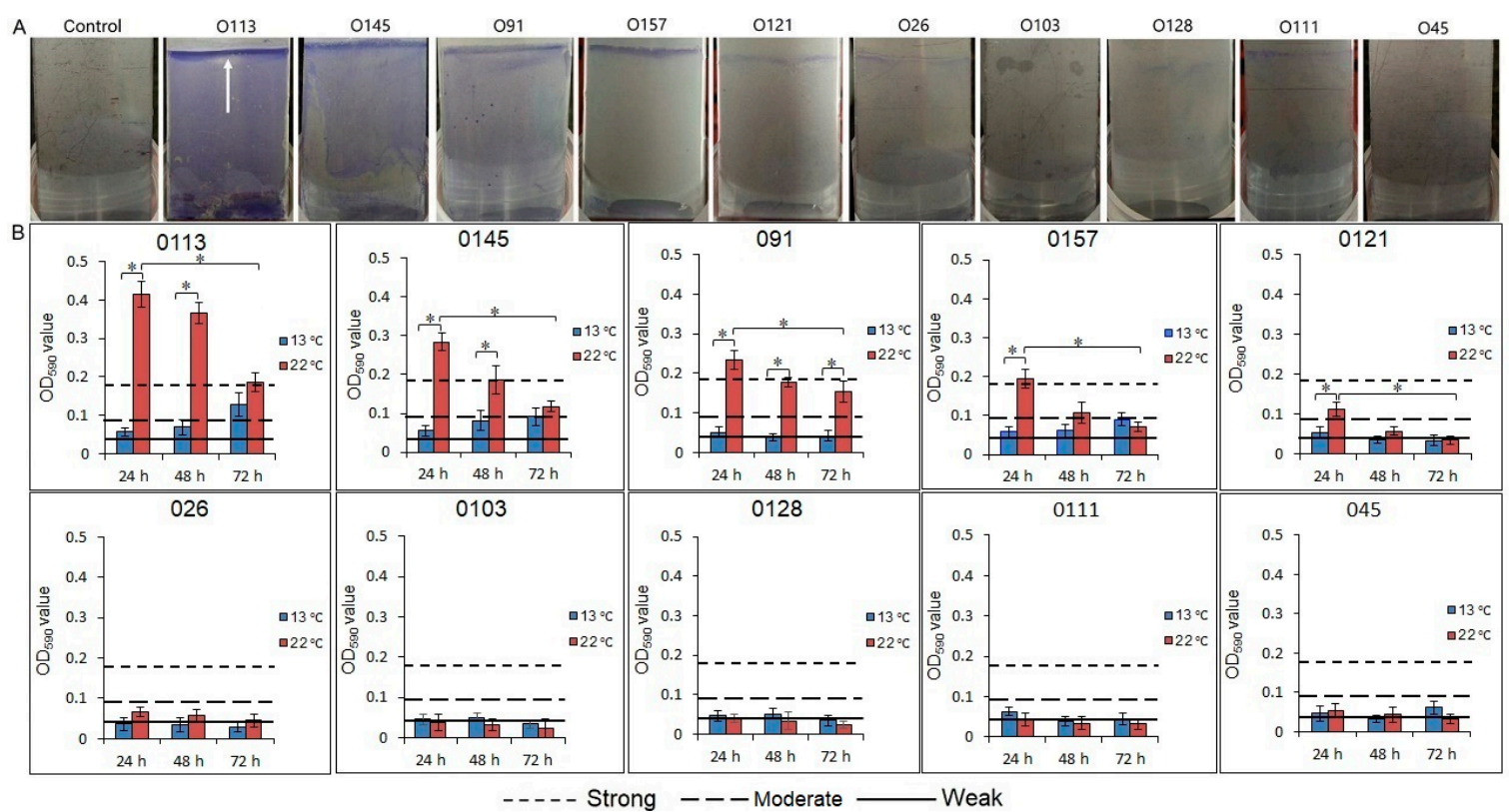

Figure 1. Biofilm formation of 10 STEC strains on a stainless steel surface. (A) Biofilms of 10 STEC strains were stained by crystal violet after incubation at $22^{\circ} \mathrm{C}$ for $24 \mathrm{~h}$. The arrow shows that some strains formed a dense pellicle at the air-liquid interface. (B) Biofilm formation of 10 STEC strains in M9 medium at $22{ }^{\circ} \mathrm{C}$ or $13{ }^{\circ} \mathrm{C}$ after 24,48 , and $72 \mathrm{~h}$. The vertical axis represents the average of OD values, determined at $590 \mathrm{~nm}$. Horizontal lines represent the cutoff values between weak, moderate, and strong biofilm producers. The cutoff optical density value (ODc) of 0.043 is defined as three standard deviations above the mean OD of the negative controls. Strains were classified as OD $\leq$ ODc (0.043), no biofilm producer, ODc $<$ OD $\leq 2 \times$ ODc, weak biofilm producers, $2 \times$ ODc $<$ OD $\leq 4 \times$ ODc, moderate biofilm producers, and $4 \times$ ODc $<$ OD, strong biofilm producers. OD, optical density, STEC, Shiga toxin-producing E. coli. Asterisk denotes significant difference $(P<0.05)$.

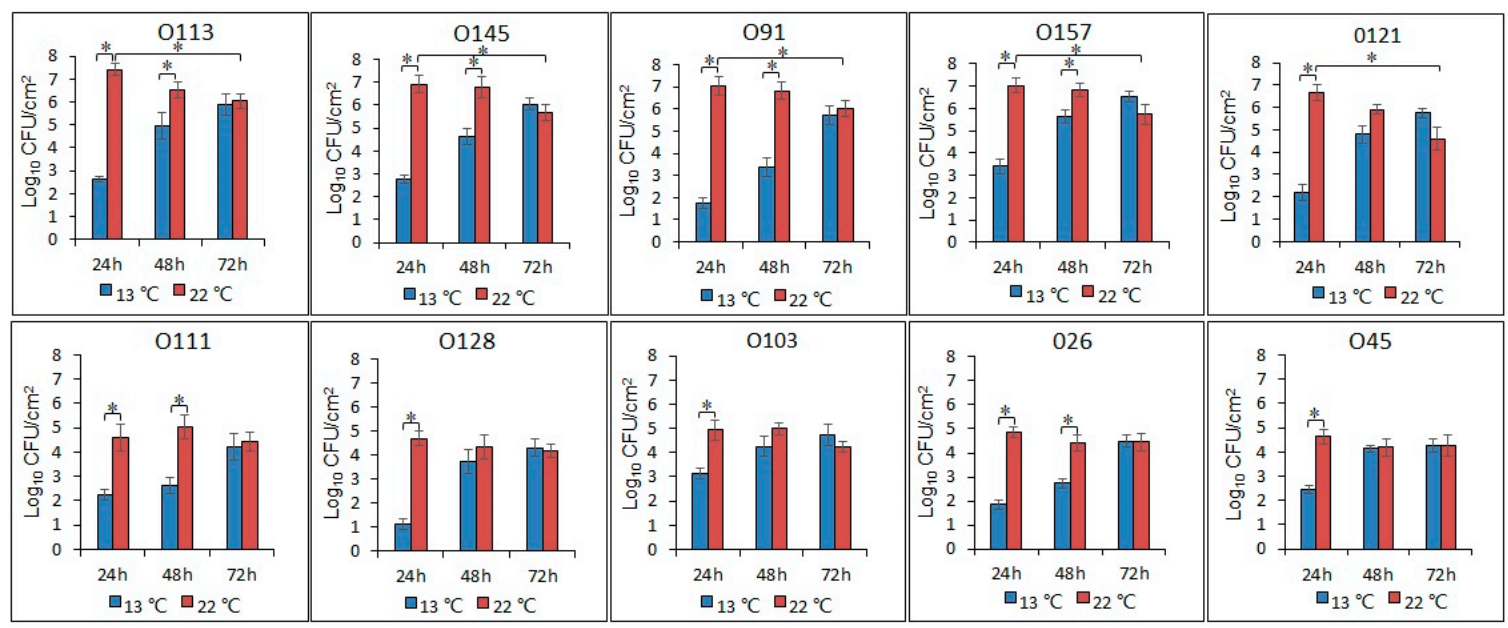

Figure 2. Number of biofilm cells of the 10 STEC isolates after incubation at $22{ }^{\circ} \mathrm{C}$ and $13{ }^{\circ} \mathrm{C}$ for 24,48 , and $72 \mathrm{~h}$. Asterisk denotes a significant difference $(P<0.05)$.

\subsection{SEM Observation}

Overall, biofilms formed by O113 (Figure 3), O145 (Figure 4), and O91 (Figure 5) at $13^{\circ} \mathrm{C}$ were dramatically different from those formed at $22{ }^{\circ} \mathrm{C}$. At $22^{\circ} \mathrm{C}$, the biofilms of strains $\mathrm{O} 113, \mathrm{O} 145$, and $\mathrm{O} 91$ consisted of multiple layers of bacterial cells and completely covered the surface of the stainless steel coupon. However, the biofilms decreased with increasing incubation time (Figure 3, Figure 4, and Figure 5). At $72 \mathrm{~h}$, although there were still some cells attached to the surface, they remained 
in monolayers and were sparsely distributed on the surface. In contrast, no cell aggregates of O113, $\mathrm{O} 145$, and $\mathrm{O} 91$ were observed on the stainless steel coupon at $13^{\circ} \mathrm{C}$ after $24 \mathrm{~h}$, with only sporadic cell aggregates observed on the surface of stainless steel after $72 \mathrm{~h}$.

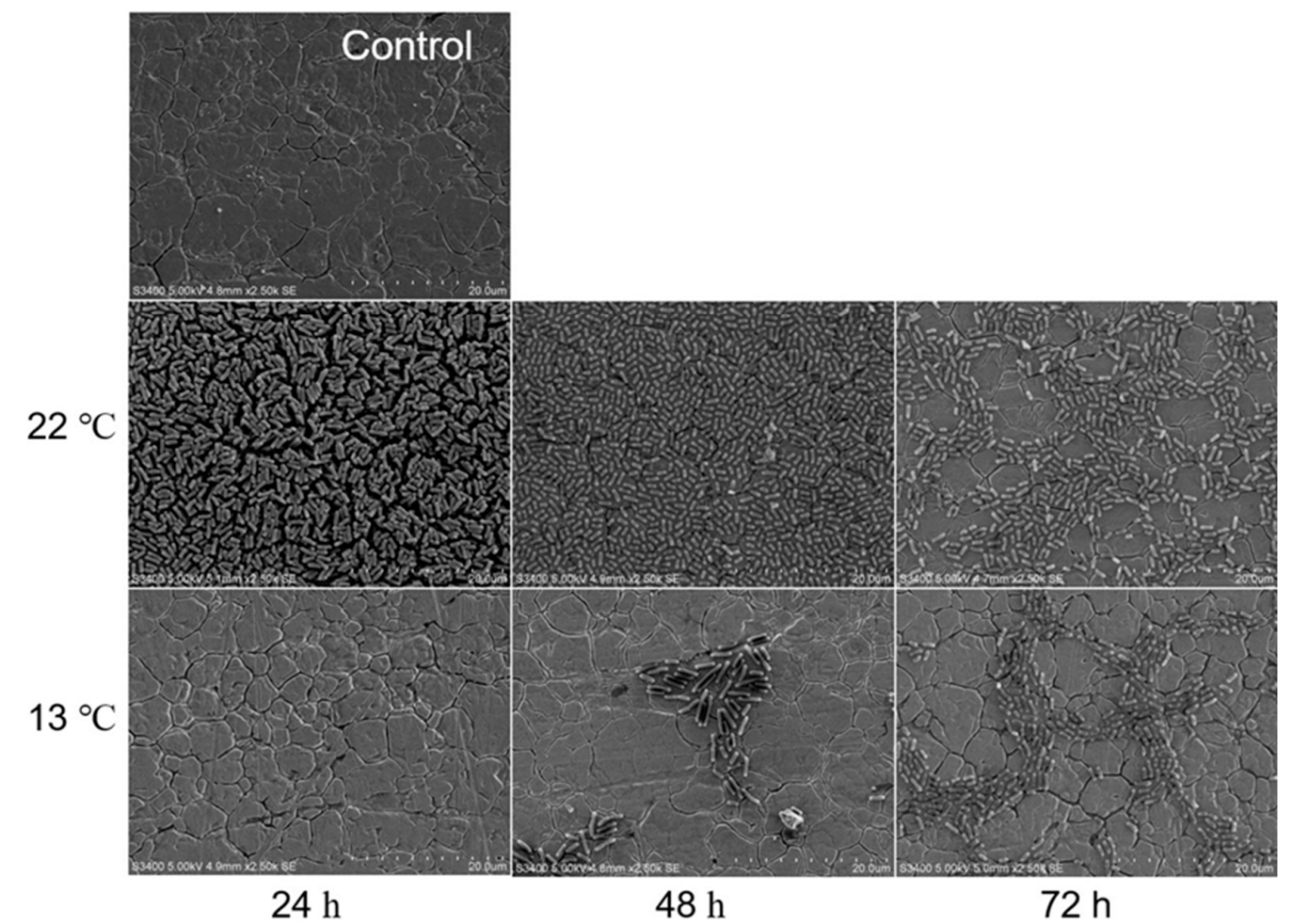

Figure 3. Representative SEM images of $\mathrm{O} 113$ biofilm grown in $\mathrm{M} 9$ medium at $22{ }^{\circ} \mathrm{C}$ and $13{ }^{\circ} \mathrm{C}$ for 24 , 48 , and $72 \mathrm{~h}$ on stainless steel coupons. Bar $=20 \mu \mathrm{m}$.

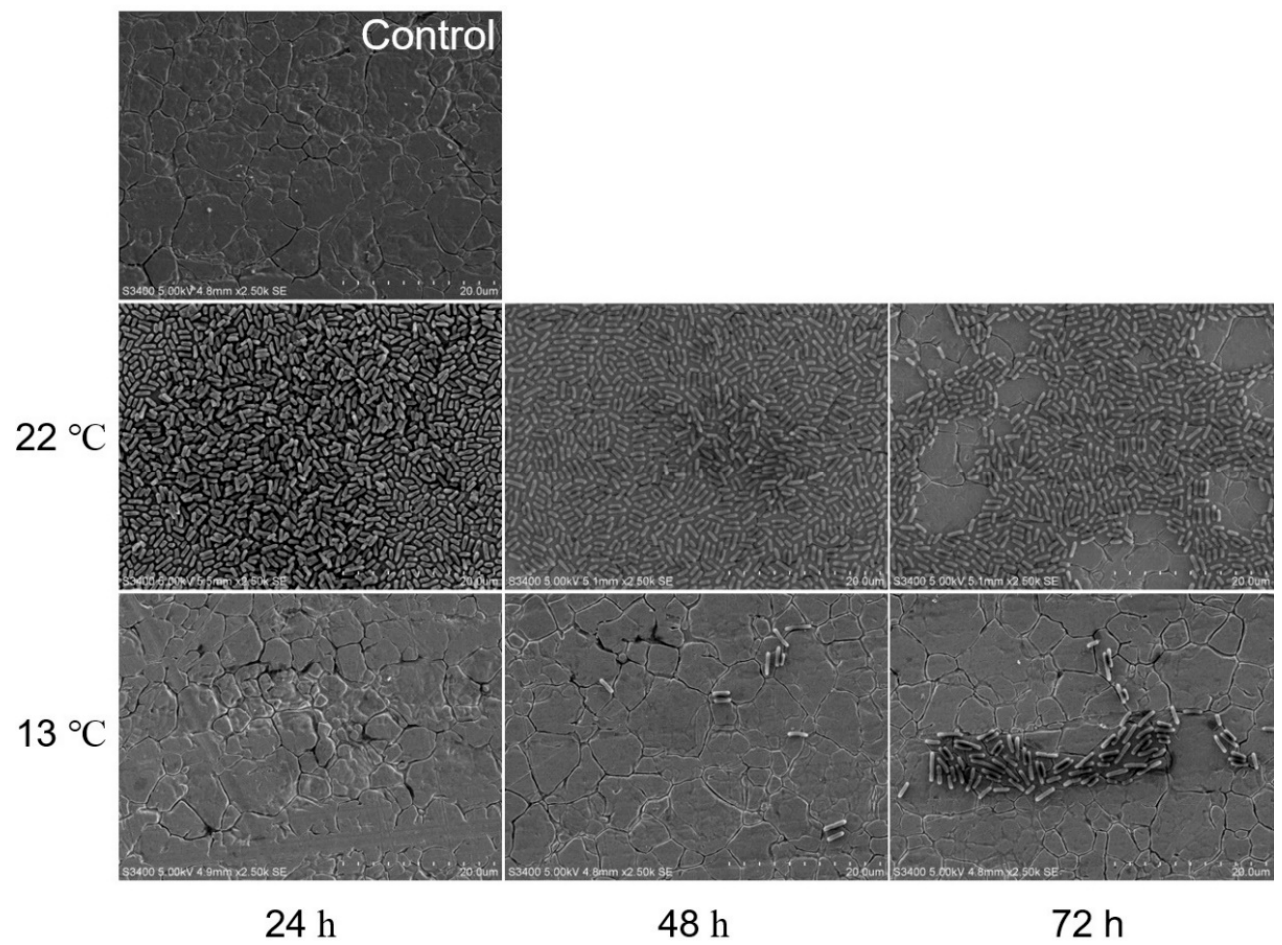

Figure 4. Representative SEM images of $\mathrm{O} 145$ biofilm grown in $\mathrm{M} 9$ medium at $22^{\circ} \mathrm{C}$ and $13{ }^{\circ} \mathrm{C}$ for 24 , 48 , and $72 \mathrm{~h}$ on stainless steel coupons. Bar $=20 \mu \mathrm{m}$. 


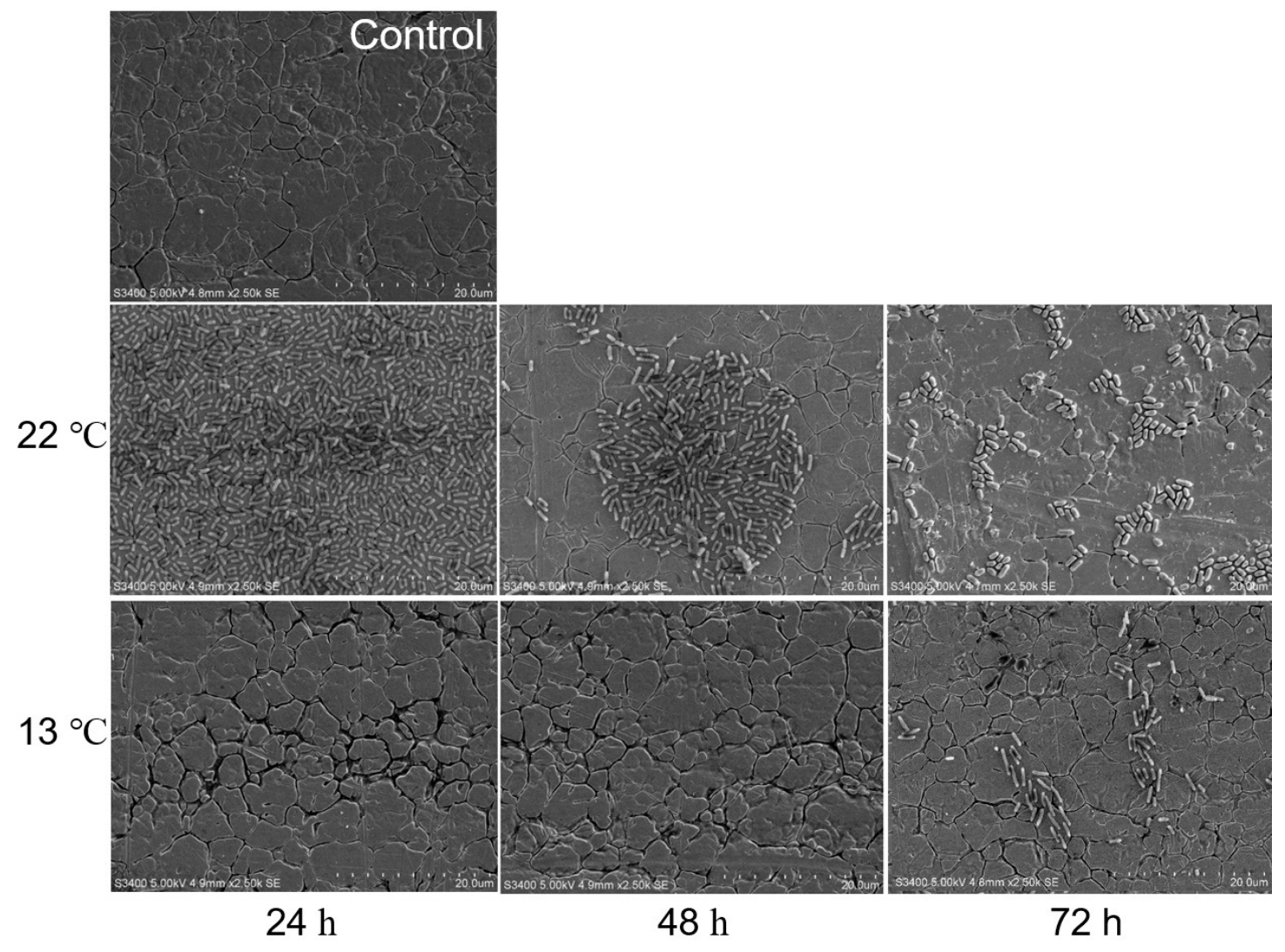

Figure 5. Representative SEM images of O91 biofilm grown in $\mathrm{M} 9$ medium at $22^{\circ} \mathrm{C}$ and $13{ }^{\circ} \mathrm{C}$ for 24 , 48 , and $72 \mathrm{~h}$ on stainless steel coupons. Bar $=20 \mu \mathrm{m}$.

\section{Discussion}

Biofilms are recognized as one of the major strategies that bacteria utilize to support survival under adverse environmental conditions [25]. Bacteria can form biofilms on a wide variety of surfaces and at air-liquid or liquid-solid interfaces $[26,27]$. Stainless steel surfaces are widely used in food processing plants $[28,29]$. However, previous studies have shown that the adhesion of Salmonella to stainless steel was significantly higher than to other materials such as rubber and polyurethane surfaces in processing plants [30]. Stainless steel appears smooth to the unaided eye, but it is actually irregular and can harbor bacterial cells when viewed under a microscope [29].

In this study, the capacity of the 10 STEC isolates varied in their ability to form biofilms on stainless steel (Figure 1A). Similar strain-dependent results were obtained from a study that compared the biofilm-forming ability on polystyrene of $18 \mathrm{O} 157: \mathrm{H7}$ strains and 33 non-O157 strains belonging to serogroups O26, O111, O103, and O145 [31]. Another feature of biofilm formation in the current study was that the isolates capable of forming biofilms formed a dense pellicle at the air-liquid interface on stainless steel (white arrows in Figure 1A). It is known that STEC biofilm formation is influenced by a variety of factors, including the characteristics of the strains, nutrient availability, temperature, and other environmental conditions [9]. Under our experimental conditions, the combination of oxygen and moisture available at the air-liquid interfaces may have played an important role in biofilm formation, which is an observation supported by others [20].

Of the 10 isolates that were previously identified as capable of forming strong or moderate biofilms on polystyrene at $22^{\circ} \mathrm{C}$ [21], five strains (O113, O145, O91, O157, and O121) were able to form strong or moderate biofilms on stainless steel at this temperature. This indicates that these bacterial isolates can survive on various food-contact surfaces, which increases the likelihood that they could contaminate food. However, the lack of ability for the other five strains (O45, O111, O26, O103, and O128) to form strong biofilms on stainless steel may be due to a number of factors. First, the properties of attachment 
surface may affect the binding strength of bacteria to the substrate. Second, the differences in the nutrient composition of media might be a contributing factor considering the fact that our previous study was conducted using LB broth [21,32], whereas M9 medium was used to grow the bacteria that formed biofilms in the current study.

At $22{ }^{\circ} \mathrm{C}$, the attached biomass of strains O113, O145, O91, O157, and $\mathrm{O} 121$ decreased with increasing incubation time. This reduction in biofilm cells was further confirmed by representative SEM images of O113, O145, and O91 (Figure 3, Figure 4, and Figure 5). Based on our previous studies [21], the biofilms of strains O113, O145, O121, O45, and O103 increased on polystyrene with incubation time, so it was expected that the density of biofilm cells of these strains would also increase on stainless steel over time. Previous studies demonstrated a linear increase in E. coli biofilm formation on stainless steel at $23^{\circ} \mathrm{C}$ [33] and $15^{\circ} \mathrm{C}$ [6] up to $24 \mathrm{~h}$. However, some studies observed a reduction in cell density in biofilms after $48 \mathrm{~h}$ [33]. These findings suggest that the biofilm medium plays a major role in the biofilm phenotype. Under static conditions, a lack of nutrients and metabolic waste accumulation in M9 during incubation may contribute to a decrease in biofilm surface populations [5]. Moreover, daughter cells of attached bacteria are often released from the surface upon completion of cell division [34]. These released cells may remain in a planktonic state, which leads to a decrease in STEC biofilm formation. Otherwise, the release of cells from STEC biofilm on stainless steel might have occurred at higher cell densities than during biofilm growth on polystyrene since biofilm cell numbers of STEC continued to increase at $22{ }^{\circ} \mathrm{C}$ [21]. Biofilms formed on stainless steel dislodge at a faster rate than those on highly hydrophobic acrylic surfaces [35]. Compared to polystyrene, stainless steel surfaces are hydrophilic and negatively charged at a neutral $\mathrm{pH}$. Since bacteria are also typically negatively charged, this surface may be less conducive to microbial colonization. In weakly charged liquids, the repulsive electrostatic forces are significant [32,36].

Low temperatures $\left(5-15^{\circ} \mathrm{C}\right)$ are generally maintained in meat processing environments [37]. Therefore, the potential for STEC strains to develop biofilms on stainless steel at $13{ }^{\circ} \mathrm{C}$ was examined. Compared to $22^{\circ} \mathrm{C}$, the biofilm formation of strains O113, O145, O91, O157, and $\mathrm{O} 121$ was dramatically inhibited at $13{ }^{\circ} \mathrm{C}$. As previously reported, temperature influences the biofilm-forming capacity of isolates [9]. Weak biofilm formation at lower temperatures could be due to the presence of fewer planktonic cells at $13{ }^{\circ} \mathrm{C}$ than at $22{ }^{\circ} \mathrm{C}$ (Figure S1). Another explanation could be that biofilm cells grew slower at lower temperatures, which results in weaker biofilms at $13{ }^{\circ} \mathrm{C}$ than at $22{ }^{\circ} \mathrm{C}$. These findings are in agreement with Dewanti and Wong [38], who observed stronger biofilm formation by STEC O157:H7 on stainless steel at $22^{\circ} \mathrm{C}$ than at $10^{\circ} \mathrm{C}$. Furthermore, the surface properties of STEC at $13{ }^{\circ} \mathrm{C}$ may be different from that grown at $22^{\circ} \mathrm{C}$. It has been shown that the cell surface hydrophobicity and fimbriae production of E. coli and Salmonella are temperature-dependent [39-41]. Adrian et al. reported that higher temperature increased the cell surface hydrophobicity level in STEC isolates [40], which is positively correlated with biofilm formation [42,43]. Furthermore, Walker et al. demonstrated that fimbriae in Salmonella were not produced at temperatures below $20{ }^{\circ} \mathrm{C}$ [41], which reduced bacterial attachment to commonly used food processing surfaces $[44,45]$. We also found that, over $72 \mathrm{~h}$ of incubation, only strain $\mathrm{O} 113$ formed a moderate biofilm at $13^{\circ} \mathrm{C}$. This biofilm-forming capacity of $\mathrm{O} 113$ may contribute to its persistence in the processing environment and influence its high relative incidence [46].

\section{Conclusions}

The findings in this study indicated that STEC isolates form biofilms in a strain-dependent manner and the process was affected by various environmental factors such as temperature, atmosphere, and incubation time. Of the ten isolates previously shown to readily form biofilms on polystyrene, only strains $\mathrm{O} 113, \mathrm{O} 145, \mathrm{O} 91, \mathrm{O} 157$, and $\mathrm{O} 121$ formed moderate to strong biofilms on stainless steel at $22{ }^{\circ} \mathrm{C}$. At $13{ }^{\circ} \mathrm{C}$, biofilm formation by strains O113, O145, O91, O157, and O121 decreased, which indicates that low temperature environments will reduce STEC biofilm formation on food contact surfaces. Further studies are underway to assess the ability of these strains to form biofilms in 
meat processing environments and to identify methods to remove and prevent biofilm development as a means of reducing the risk of food contamination.

Supplementary Materials: The following are available online at http:/ /www.mdpi.com/2076-2607/7/4/95/s1.

Author Contributions: Z.M., K.S., Y.D.N., and T.A.M. designed the study. Z.M. performed the experiments. Z.M. and K.S. analyzed the data. Z.M. wrote the manuscript. K.S., Y.D.N., E.W.B., T.A.M., and X.B revised the manuscript. T.A.M., C.N., and K.S. provided technical assistance.

Funding: Funding support was provided from Agriculture and Agri-Food Canada, Alberta Agriculture and Forestry, the China Scholarship Council and Xianqin Yang and Claudia Narvaez through a Beef Cattle Research Council Beef Cluster grant.

Acknowledgments: We acknowledge the technical assistance of R. Ha, C. Conrad, R. Barbieri, S. Trapp, and Y. Graham during the study as well as Roger Johnson (PHAC) for provision of STEC strains.

Conflicts of Interest: The authors declare no conflict of interest.

\section{References}

1. Dzieciol, M.; Schornsteiner, E.; Muhterem, M.; Stessl, B.; Wagner, M.; Schmitz-Esser, S. Bacterial diversity of floor drain biofilms and drain waters in a Listeria monocytogenes contaminated food processing environment. Int. J. Food Microbiol. 2016, 223, 33-40. [CrossRef] [PubMed]

2. Al-Adawi, A.S.; Gaylarde, C.C.; Sunner, J.; Beech, I.B. Transfer of bacteria between stainless steel and chicken meat: a CLSM and DGGE study of biofilms. AIMS Microbiol. 2016, 2, 340-358. [CrossRef]

3. Wang, H.; Zhang, X.; Zhang, Q.; Ye, K.; Xu, X.; Zhou, G. Comparison of microbial transfer rates from Salmonella spp. biofilm growth on stainless steel to selected processed and raw meat. Food Control 2015, 50, 574-580. [CrossRef]

4. Gibson, H.; Taylor, J.; Hall, K.; Holah, J. Effectiveness of cleaning techniques used in the food industry in terms of the removal of bacterial biofilms. J. Appl. Microbiol. 1999, 87, 41-48. [CrossRef] [PubMed]

5. Vogeleer, P.; Tremblay, Y.D.; Jubelin, G.; Jacques, M.; Harel, J. Biofilm-forming abilities of Shiga toxin-producing Escherichia coli isolates associated with human infections. Appl. Environ. Microbiol. 2016, 82, 1448-1458. [CrossRef] [PubMed]

6. Dourou, D.; Beauchamp, C.S.; Yoon, Y.; Geornaras, I.; Belk, K.E.; Smith, G.C.; Nychas, G.-J.E.; Sofos, J.N. Attachment and biofilm formation by Escherichia coli O157:H7 at different temperatures, on various food-contact surfaces encountered in beef processing. Int. J. Food Microbiol. 2011, 149, 262-268. [CrossRef] [PubMed]

7. Petrova, O.E.; Sauer, K. Escaping the biofilm in more than one way: desorption, detachment or dispersion. Curr. Opin. Microbiol. 2016, 30, 67-78. [CrossRef] [PubMed]

8. Ryu, J.H.; Beuchat, L.R. Biofilm formation by Escherichia coli O157:H7 on stainless steel: Effect of exopolysaccharide and curli production on its resistance to chlorine. Appl. Environ. Microbiol. 2005, 71, 247-254. [CrossRef] [PubMed]

9. Ryu, J.H.; Kim, H.; Beuchat, L.R. Attachment and biofilm formation by Escherichia coli O157:H7 on stainless steel as influenced by exopolysaccharide production, nutrient availability, and temperature. J. Food Prot. 2004, 67, 2123-2131. [CrossRef] [PubMed]

10. Caprioli, A.; Scavia, G.; Morabito, S. Public health microbiology of Shiga toxin-producing Escherichia coli. In Enterohemorrhagic Escherichia coli and Other Shiga Toxin-Producing E. coli, 1st ed.; Vanessa, S., Carolyn, J.H., Eds.; American Society of Microbiology: Washington, DC, USA, 2015; pp. 263-295.

11. Fakhouri, F.; Zuber, J.; Frémeaux-Bacchi, V.; Loirat, C. Haemolytic uraemic syndrome. Lancet 2017, 390, 681-696. [CrossRef]

12. Public Health Agency of Canada. National Enteric Surveillance Program (NESP): Annual summary 2016; Public Health Agency of Canada: Ottawa, ON, Canada, 2016.

13. Luna-Gierke, R.; Griffin, P.; Gould, L.; Herman, K.; Bopp, C.; Strockbine, N.; Mody, R. Outbreaks of non-O157 Shiga toxin-producing Escherichia coli infection: USA. Epidemiol. Infect. 2014, 142, 2270-2280. [CrossRef] [PubMed] 
14. Park, S.; Kim, S.H.; Seo, J.J.; Kee, H.Y.; Kim, M.J.; Seo, K.W.; Lee, D.H.; Choi, Y.H.; Lim, D.J.; Hur, Y.J. An outbreak of inapparent non-O157 enterohemorrhagic Escherichia coli infection. Korean J. Med. 2006, 70, 495-504.

15. Yatsuyanagi, J.; Saito, S.; Ito, I.J. A case of hemolytic-uremic syndrome associated with Shiga toxin 2-producing Escherichia coli O121 infection caused by drinking water contaminated with bovine feces. Jpn. J. Infect. Dis. 2002, 55, 174-176. [PubMed]

16. Reid, T.M.S. A case study of cheese associated E. coli $\mathrm{O} 157$ outbreaks in Scotland. In Verocytotoxigenic Escherichia coli, 2nd ed.; Duffy, G., Garvey, P., McDowell, D., Eds.; Food and Nutrition: Hartford, CT, USA, 2001; pp. 201-212.

17. Adator, E.H.; Cheng, M.; Holley, R.; McAllister, T.; Narvaez-Bravo, C. Ability of Shiga toxigenic Escherichia coli to survive within dry-surface biofilms and transfer to fresh lettuce. Int. J. Food Microbiol. 2018, 269, 52-59. [CrossRef] [PubMed]

18. Wang, R.; Luedtke, B.E.; Bosilevac, J.M.; Schmidt, J.W.; Kalchayanand, N.; Arthur, T.M. Escherichia coli O157:H7 strains isolated from high-event period beef contamination have strong biofilm-forming ability and low sanitizer susceptibility, which are associated with high pO157 plasmid copy number. J. Food Prot. 2016, 79, 1875-1883. [CrossRef]

19. Sharma, V.K.; Kudva, I.T.; Bearson, B.L.; Stasko, J.A. Contributions of EspA filaments and curli fimbriae in cellular adherence and biofilm formation of enterohemorrhagic Escherichia coli O157:H7. PLoS ONE 2016, 11, e0149745. [CrossRef] [PubMed]

20. Wang, R.; Bono, J.L.; Kalchayanand, N.; Shackelford, S.; Harhay, D.M. Biofilm formation by Shiga toxin-producing Escherichia coli O157:H7 and Non-O157 strains and their tolerance to sanitizers commonly used in the food processing environment. J. Food Prot. 2012, 75, 1418-1428. [CrossRef] [PubMed]

21. Wang, J.; Stanford, K.; McAllister, T.A.; Johnson, R.P.; Chen, J.; Hou, H.; Zhang, G.; Niu, Y.D. Biofilm formation, virulence gene profiles, and antimicrobial resistance of nine serogroups of non-O157 Shiga toxin-producing Escherichia coli. Foodborne Pathog. Dis. 2016, 13, 316-324. [CrossRef] [PubMed]

22. Ramírez, M.D.; Groot, M.N.; Smid, E.J.; Hols, P.; Kleerebezem, M.; Abee, T. Role of cell surface composition and lysis in static biofilm formation by Lactobacillus plantarum WCFS1. Int. J. Food Microbiol. 2018, 271, 15-23. [CrossRef]

23. Dhowlaghar, N.; Bansal, M.; Schilling, M.W.; Nannapaneni, R.J. Scanning electron microscopy of Salmonella biofilms on various food-contact surfaces in catfish mucus. Food Microbiol. 2018, 74, 143-150. [CrossRef]

24. Stepanović, S.; Vuković, D.; Dakić, I.; Savić, B.; Švabić-Vlahović, M.J. A modified microtiter-plate test for quantification of staphylococcal biofilm formation. J. Microbiol. Methods 2000, 40, 175-179. [CrossRef]

25. Fuente-Núñez, C.; Reffuveille, F.; Fernández, L.; Hancock, R.E. Bacterial biofilm development as a multicellular adaptation: Antibiotic resistance and new therapeutic strategies. Curr. Opin. Microbiol. 2013, 16, 580-589. [CrossRef] [PubMed]

26. Prado, D.B.; Fernandes, M.S.; Anjos, M.M.; Tognim, M.C.; Nakamura, C.V.; Machinski Junior, M.; Mikcha, J.M.; Abreu Filho, B.A. Biofilm-forming ability of Alicyclobacillus spp. isolates from orange juice concentrate processing plant. J. Food Saf. 2018, e12466. [CrossRef]

27. Medrano-Félix, J.A.; Chaidez, C.; Mena, K.D.; Socorro, M.; Castro, N. Characterization of biofilm formation by Salmonella enterica at the air-liquid interface in aquatic environments. Environ. Monit. Assess. 2018, 190, 221. [CrossRef] [PubMed]

28. Hilbert, L.R.; Bagge-Ravn, D.; Kold, J.; Gram, L.J. Influence of surface roughness of stainless steel on microbial adhesion and corrosion resistance. Int. Biodeterior. Biodegr. 2003, 52, 175-185. [CrossRef]

29. Giaouris, E.; Chorianopoulos, N.; Nychas, G.J. Effect of temperature, pH, and water activity on biofilm formation by Salmonella enterica enteritidis PT4 on stainless steel surfaces as indicated by the bead vortexing method and conductance measurements. J. Food Prot. 2005, 68, 2149-2154. [CrossRef]

30. Chia, T.; Goulter, R.; McMeekin, T.; Dykes, G.; Fegan, N.J. Attachment of different Salmonella serovars to materials commonly used in a poultry processing plant. Food Microbiol. 2009, 26, 853-859. [CrossRef]

31. Biscola, F.T.; Abe, C.M.; Guth, B.E. Determination of adhesin gene sequences in, and biofilm formation by, O157 and Non-O157 Shiga toxin-producing Escherichia coli strains isolated from different sources. Appl. Environ. Microbiol. 2011, 77, 2201-2208. [CrossRef] [PubMed]

32. Dewanti, R.; Wong, A.C. Influence of culture conditions on biofilm formation by Escherichia coli O157:H7. Int. J. Food Microbiol. 1995, 26, 147-164. [CrossRef] 
33. Nguyen, H.; Yang, Y.; Yuk, H. Biofilm formation of Salmonella Typhimurium on stainless steel and acrylic surfaces as affected by temperature and pH level. LWT-Food Sci. Technol. 2014, 55, 383-388. [CrossRef]

34. Sinde, E.; Carballo, J.J. Attachment of Salmonella spp. and Listeria monocytogenes to stainless steel, rubber and polytetrafluorethylene: The influence of free energy and the effect of commercial sanitizers. Food Microbiol. 2000, 17, 439-447. [CrossRef]

35. Bakterij, A.J. An overview of the influence of stainless-steel surface properties on bacterial adhesion. Mater. Tehnol. 2014, 48, 609-617.

36. Hood, S.K.; Zottola, E.A. Adherence to stainless steel by foodborne microorganisms during growth in model food systems. Int. J. Food Microbiol. 1997, 37, 145-153. [CrossRef]

37. Somers, E.B.; LEE, A.C. Efficacy of two cleaning and sanitizing combinations on Listeria monocytogenes biofilms formed at low temperature on a variety of materials in the presence of ready-to-eat meat residue. J. Food Prot. 2004, 67, 2218-2229. [CrossRef]

38. Frank, J.F. Microbial attachment to food and food contact surfaces. In Advances in Food and Nutrition Research; Academic Press: Cambridge, MA, USA, 2001; Volume 43, pp. 319-370.

39. Andersen, T.E.; Kingshott, P.; Palarasah, Y.; Benter, M.; Alei, M.; Kolmos, H.J. A flow chamber assay for quantitative evaluation of bacterial surface colonization used to investigate the influence of temperature and surface hydrophilicity on the biofilm forming capacity of uropathogenic Escherichia coli. J. Microbiol. Methods 2010, 81, 135-140. [CrossRef]

40. Cookson, A.L.; Cooley, W.A.; Woodward, M.J. The role of type 1 and curli fimbriae of Shiga toxin-producing Escherichia coli in adherence to abiotic surfaces. Int. J. Food Microbiol. 2002, 292, 195-205. [CrossRef]

41. Walker, S.L.; SOJKA, M.; Dibb-fuller, M.; Woodward, M.J. Effect of pH, temperature and surface contact on the elaboration of fimbriae and flagella by Salmonella serotype Enteritidis. J. Med. Microbiol. 1999, 48, $253-261$. [CrossRef]

42. Bonaventura, G.; Piccolomini, R.; Paludi, D.; Dorio, V.; Vergara, A.; Conter, M.; Ianieri, A.J. Influence of temperature on biofilm formation by Listeria monocytogenes on various food-contact surfaces: Relationship with motility and cell surface hydrophobicity. J. Appl. Microbiol. 2008, 104, 1552-1561. [CrossRef] [PubMed]

43. Liu, Y.; Yang, S.F.; Li, Y.; Xu, H.; Qin, L.; Tay, J.H. The influence of cell and substratum surface hydrophobicities on microbial attachment. J. Biotechnol. 2004, 110, 251-256. [CrossRef]

44. Jain, S.; Chen, J.J. Attachment and biofilm formation by various serotypes of Salmonella as influenced by cellulose production and thin aggregative fimbriae biosynthesis. J. Food Prot. 2007, 70, 2473-2479. [CrossRef]

45. Cogan, T.A.; Rgensen, F.; Lappin-Scott, H.M.; Benson, C.E.; Woodward, M.J.; Humphrey, T.J. Flagella and curli fimbriae are important for the growth of Salmonella enterica serovars in hen eggs. Microbiology 2004, 150, 1063. [CrossRef] [PubMed]

46. Paton, A.W.; Woodrow, M.C.; Doyle, R.M.; Lanser, J.A.; Paton, J.C. Molecular characterization of a Shiga toxigenic Escherichia coli O113: H21 strain lacking eae responsible for a cluster of cases of hemolytic-uremic syndrome. J. Clin. Microbiol. 1999, 37, 3357-3361. [PubMed]

(C) 2019 by the authors. Licensee MDPI, Basel, Switzerland. This article is an open access article distributed under the terms and conditions of the Creative Commons Attribution (CC BY) license (http://creativecommons.org/licenses/by/4.0/). 